\title{
Penerapan Layanan Bimbingan Konseling Oleh Guru Kelas Di SD Negeri 43 Banda Aceh
}

\author{
Hafidh Maksum, Faisal Anwar \\ Dosen Fakultas Keguruan dan Ilmu Pendidikan Universitas Serambi Mekkah \\ Hafidh.maksum@serambimekkah.ac.id
}

\begin{abstract}
Abstrak
Adapun tujuan dalam penelitian ini untuk mengetahui penerapan layanan bimbingan konseling oleh Guru Kelas di SD Negeri 43 Banda Aceh. Subjek pada penelitian ini adalah 6 orang guru kelas di SD Negeri 43 Banda Aceh. Teknik analisis data menggunakan observasi, wawancara dan dokumentasi. Data dianalisis menggunakan data reduction, data display, dan conclusion drawing/verification. Hasil penelitian menunjukkan bahwa Penerapan layanan bimbingan konseling telah dilakukan oleh guru kelas di SD Negeri 43 Banda Aceh. Guru melakukan bimbingan konseling dengan cara mengidentifikasi permasalahan yang dihadapi siswa berkaitan dengan pembelajaran di dalam kelas maupun di luar kelas. Setelah mengetahui siswa yang bermaslah dan membutuhkan layanan bimbingan, guru memberikan arahan dan bantuan bagi siswa agar dapat mecari solusi dari permasalahan yang dihadapi. Guru menghadapi kendala dalam penerapan layanan bimbingan konseling di SD Negeri 43 Banda Aceh seperti keterbatasan waktu yang dimiliki oleh guru dikarenakan tugas guru kelas yang merangkap sebagai pendidik dan pengajar, guru hanya dapat mengawasi siswa di kelas, sehingga saat di luar kelas guru tidak terlalu memahami kondisi anak. Tidak adanya perubahan yang signifikan dari siswa juga menjadi kendala bagi guru.
\end{abstract}

\section{Kata Kunci: Layanan Bimbingan Konseling, Guru Kelas}

\section{PENDAHULUAN}

Bimbingan Konseling merupakan elemen yang membantu siswa untuk mencapai tahap-tahap perkembangannya (Sutirna, 2013:18). Perkembangan tersebut meliputi aspek pribadi-sosial, akademik, dan karir. Untuk mencapai tahap perkembangannya siswa diharapkan mampu menyesuaikan diri dengan kondisi perubahannya. Di dalam proses menyesuaikan diri ini siswa seringkali mengalami hambatan dan kesulitan, sehingga dengan layanan bimbingan konseling secara terprogram dan terarah siswa dapat terbantu untuk menyesuaikan diri dengan setiap perubahan.

Layanan bimbingan dan konseling (BK) hakikatnya merupakan usaha memfasilitasi perkembangan nilai-nilai dan kompetensi kehidupan melalui proses interaksi yang empatik antara guru BK/konselor dengan peserta didik/siswa (konseli). Komponen dalam kegiatan layanan BK mencakup aspek nilai dan sikap yang terkait dengan perkembangan diri, ketabahan, dan tanggung jawab (Luddin, 2016: 218). Di samping itu, Radjah (2016: 90) menambahkan landasan motif altruistik, empatik, menghormati dan menghargai keragaman konseli diperlukan bagi seorang konselor dalam kegiatan layanan bimbingan dan konseling.

Dengan diterbitkannya Permendikbud Nomor 111 Tahun 2014 Tentang Bimbingan dan Konseling Pada Pendidikan dasar dan Menengah ,maka semakin kokoh kedudukan bimbingan dan konseling di sekolah terutama pada pendidikan dasar dan menengah. Peraturan menteri ini juga sebagai pijakan atau rujukan Guru Bimbingan dan Konseling atau Konselor dalam melaksanakan tugas Layanan Bimbingan dan Konseling 
di sekolah terutama permasalahan jam masuk kelas yang selama ini menjadi perdebatan. Dalam pasal 6 ayat ( 4 ) dijelaskan bahwa " Layanan Bimbingan dan Konseling sebagaimana dimaksud pada ayat (3) yang diselenggarakan di dalam kelas dengan beban belajar 2 ( dua ) jam perminggu"

Guru sebagai pemberi layanan bimbingan konseling harus benar-benar memahami penuh hal-hal yang harus diberikan kepada peserta didik. Pelaksanaan layanan bimbingan konseling disekolah dasar dapat diimplementasikan dengan berbagai konsep seperti konsep islami maupun dengan konsep ramah anak, untuk mewujudkan tujuan bimbingan konseling yang diharapkan. Menuurt Prayitno (2013:12) Pelaksanaan layanan bimbingan konseling memiliki beberapa jenis layanan bimbingan konseling seperti, Layanan Orientasi, Layanan Informasi, Layanan Pembelajaran, Layanan Penempatan dan Penyaluran, Layanan Penguasaan Konten, Layanan Konseling Perorangan, Layanan Bimbingan Kelompok, Layanan Konseling Kelompok, Layanan Konsultasi, Layanan Mediasi, Dukungan Sistem.

Hasil observasi di SD Negeri 43 Banda Aceh menunjukkan bahwa layanan bimbingan konseling yang dilakukan di sekolah tersebut bahwasanya layanan yang diberikan kepada siswa belum maksimal. Siswa sangat jarang mendapatkan layanan bimbingan konseling. Siswa yang bermasalah biasanya hanya ditangani oleh guru kelas. Sehingga, permasalahan yang dilakukan oleh siswa dapat diselesaikan dan tidak terulang kembali. Kondisi ini mengakibatkan guru kelas dapat memberikan konseling dengan baik, guru hanya dapat menangani satu atau dua orang siswa yang bermasalah. Sedangkan siswa lainnya tidak tertantangi dengan baik.

Berdasarkan pemaparan di atas maka peneliti memandang perlu diadakan suatu penelitian lebih lanjut terkait dengan pelaksanaan layanan bimbingan belajar di sekolah agar dapat diperoleh data yang lebih mendalam peneliti memilih judul "Penerapan Layanan Bimbingan Konseling oleh Guru Kelas Di SD Negeri 43 Banda Aceh"

\section{Tujuan Penelitian}

Adpaun tujuan dalam penelitian ini adalah untuk mengetahui penerapan layanan bimbingan konseling oleh Guru Kelas di SD Negeri 43 Banda Aceh.

\section{LANDASAN TEORI}

\section{Penerapan layanan bimbingan dan konseling}

Setelah layanan bimbingan dan konseling tersusun secara terarah dan sistematis, maka langkah selanjutnya adalah pelaksanaan layanan tersebut dengan kata lain merealisasikan program. Inilah yang dimaksud dengan kegiatan penerapan program bimbungan dan konsling. Suatu program kegiatan yang ideal mencakup tiga tahapan yaitu: perencanaan, penerapan (merealisasi), dan evaluasi. Begitu juga dengan program bimbingan dan konseling setelah direncanakan direalisasikan lalu dievaluasi. Tujuan evaluasi program bimbingan konseling adalah untuk menentukan apakah program bimbingan baik, kurang baik, berhasil kurang berhasil.

\section{Indikator Konseling}

Konseling adalah suaru proses yang terjadi dalam hubungan seseorang dengan seseorang yaitu individu yang mengalami masalah yang tak dapat diatasinya, dengan seorang petugas profesional yang telah memperoleh latihan dan pengalaman untuk membantu agar klien memecahkan kesulitanya. Konseling individual yaitu layanan bimbingan dan konseling yang memungkinkan peserta didik atau konseli mendapatkan 
layanan langsung tatap muka (secara perorangan) dengan guru pembimbing dalam rangka pembahasan pengentasan masalah pribadi yang di derita konseling.

Berdasrkan uraian di atas peneliti menyusun indikator sebagai mana yang disampaikan Sardiman (2001) berikut:

1. Pelaksanaann layanan bimbingan

2. Bentuk bimbingan yang diberikan siswa

3. Fungsi layanan bimbingan

4. Cara guru memberikan bimbingan

5. Dampak bimbingan konseling

6. Tat cara pelaksanaan yang meliputi waktu, materi dan kendala serta manfaat

\section{Guru Kelas sebagai Guru BK}

Guru kelas adalah guru yang mengikuti kelas pada satuan pendidikan sekolah dasar atau yang sederajat, yang bertugas melaksanakan pembelajaran seluruh mata pelajaran pada satuan pendidikan tersebut. Implementasi kegiatan BK dalam pelaksanaan Kurikulum Berbasis Kompetensi sangat menentukan keberhasilan proses belajar-mengajar. Oleh karena itu peranan guru kelas dalam pelaksanaan kegiatan BK sangat penting dalam rangka mengefektifkan pencapaian tujuan pembelajaran yang dirumuskan.

Sardiman (2001:142) menyatakan bahwa ada sembilan peran guru kelas dalam kegiatan BK, yaitu:

a. Informator, guru diharapkan sebagai pelaksana cara mengajar informatif, laboratorium, studi lapangan, dan sumber informasi kegiatan akademik maupun umum.

b. Organisator, guru sebagai pengelola kegiatan akademik, silabus, jadwal pelajaran dan lain-lain.

c. Motivator, guru harus mampu merangsang dan memberikan dorongan serta reinforcement untuk mendinamisasikan potensi siswa, menumbuhkan swadaya (aktivitas) dan daya cipta (kreativitas) sehingga akan terjadi dinamika di dalam proses belajar-mengajar.

d. Director, guru harus dapat membimbing dan mengarahkan kegiatan belajar siswa sesuai dengan tujuan yang dicita-citakan.

e. Inisiator, guru sebagai pencetus ide dalam proses belajar-mengajar.

f. Transmitter, guru bertindak selaku penyebar kebijaksanaan dalam pendidikan dan pengetahuan.

g. Fasilitator, guru akan memberikan fasilitas atau kemudahan dalam proses belajar-mengajar.

h. Mediator, guru sebagai penengah dalam kegiatan belajar siswa.

i. Evaluator, guru mempunyai otoritas untuk menilai prestasi anak didik dalam bidang akademik maupun tingkah laku sosialnya, sehingga dapat menentukan bagaimana anak didiknya berhasil atau tidak.

\section{METODE PENELITIAN}

\section{Lokasi Penelitian}

Penelitian ini dilaksanakan di SD Negeri 43 Banda Aceh. Penelitian ini dilaksanakan pada bulan Agustus 2020.

\section{Subjek Penelitian}


Subjek pada penelitian ini adalah 6 orang guru kelas di SD Negeri 43 Banda Aceh. Peneliti mengambil subjek dalam penelitian ini dengan menggunakan teknik purposive sampling. Menurut Sugiyono (2017:87) purpossive sampling adalah: teknik untuk menentukan sampel penelitian dengan beberapa pertimbangan tertentu yang bertujuan agar data yang diperoleh nantinya bisa lebih representatif.

\section{Teknik Pengumpulan Data} observasi.

Data peneliti ini dikumpulkan melalui beberapa teknik, yaitu wawancara dan

\section{Teknik Analisis Data}

Untuk mendeskripsikan penerapan peraturan sekolah dan disiplin terhadap hasil belajar, hasil pengumpulan data dengan wawancara dan observasi akan dianalisis dengan tiga tahap analisis data kualitatif seperti dijelaskan oleh Miles dan Huberman (dalam Sugiyono, 2017:337) bahwa "aktivitas dalam analisa data kualitatif dilakukan secara interaktif dan berlangsung secara terus-menerus sampai tuntas". Aktivitas dalam analisis data yaitu data reduction, data display, dan conclusion drawing/verification.

\section{HASIL PENELITIAN DAN PEMBAHASAN Hasil Penelitian}

Hasil penelitian ini dibagi atas dua bagian, yaitu observasi dan wawancara. Peneliti melakukan wawancara dengan guru. Peneliti menjabarkan hasil penelitian sebagai berikut.

\section{Hasil Analisis Observasi}

Peneliti melakukan observasi kepada guru, hasil observasi yang telah dilakukan dijabarkan sebagai berikut :

\begin{tabular}{|c|c|c|c|}
\hline No & Pengamatan & Ya & Tidak \\
\hline 1 & $\begin{array}{l}\text { Guru memberikan bimbingan konseling } \\
\text { kepada anak yang bermasalah }\end{array}$ & $\sqrt{ }$ & \\
\hline 2 & Guru mengidentifikasikan kondisi siswa & $\sqrt{ }$ & \\
\hline 3 & $\begin{array}{l}\text { Guru memberikan bimbingan } \\
\text { pendekatan individu dengan siswa }\end{array}$ & $\sqrt{ }$ & \\
\hline 4 & $\begin{array}{l}\text { Guru mengarahkan siswa untuk melakukan } \\
\text { hal-hal yang positif }\end{array}$ & $\sqrt{ }$ & \\
\hline 5 & $\begin{array}{l}\text { Guru memberitahukan dampak perilaku } \\
\text { menyimpang bagi siswa }\end{array}$ & $\sqrt{ }$ & \\
\hline 6 & $\begin{array}{l}\text { Guru menyampaikan hal-hal yang harus } \\
\text { dilakukan siswa }\end{array}$ & $\sqrt{ }$ & \\
\hline 7 & $\begin{array}{l}\text { Guru menegaskan hal-hal yang harus } \\
\text { dihindari siswa }\end{array}$ & $\sqrt{ }$ & \\
\hline 8 & $\begin{array}{l}\text { Guru melakukan evaluasi terhadap } \\
\text { perkembangan perilaku siswa }\end{array}$ & $\sqrt{ }$ & \\
\hline 9 & $\begin{array}{l}\text { Guru melakukan bimbingan berulang kali } \\
\text { bagi siswa }\end{array}$ & $\sqrt{ }$ & \\
\hline 10 & $\begin{array}{l}\text { Guru memberikan nasihat secara lemah } \\
\text { lembut pada siswa }\end{array}$ & $\sqrt{ }$ & \\
\hline
\end{tabular}

Berdasarkan hasil pengamatan observasi diatas dapat disimpulkan bahwa guru selalu memberikan bimbingan konseling kepada anak, guru mengidentifikasikan 
kondisi siswa, guru selalu memberikan bimbingan melalui pendekatan individual selanjutnya guru mengarahkan siswa untuk melakukan hal-hal yang positif dan guru menegaskan hal-hal yang harus dihindari siswa, dan melakukan evaluasi terhadap perkembangan perilaku siswa. guru terus memberikan bimbingan berulang kepada siswa dan menasehati siswa.

\section{Hasil Analisis Wawancara}

Peneliti melakukan wawancara dengan guru. Hasil analisis wawancara dijabarkan sebagai berikut:

1. Bagaimanakah layanan bimbingan konseling di sekolah ini?

Hasil wawancara dengan guru kelas I yang berinisial RS menyatakan bahwa kita akan mengetahui karkateristik dan perkembangan siswa dengan aspek yang menyimbuh kearah yang baik, hasil wawancara dengan guru kelas II dengan inisial EL menyatakan ya, Alhamdulillah kalau bimbingan disekolah kita ini cukup memadai yang bahwasanya antara anak-anak siswa ke guru-guru SD Negeri 43 itu saling bekerjasama dan begitu juga kepada anak-anak patuh kepada guru-guru PPL.

Guru kelas III dengan inisial FD menyatakan anak bermasalah di selesaikan, apabila tidak tuntas di panggil ke ruang kepala sekolah, selanjutnya guru kelas IV dengan inisial MR menyatakan bahwa Alhamdulillah bagus kita usahakan bimbingan di sekolah ini, bisa berjalan dengan lancar.

Guru kelas V dengan Inisial MW menyatakan bahwa bagus, sedangkan guru kelas VI dengan inisial EL menyatakan bahwa kalau disekolah kami itu sebenarnya bimbingan konseling itu bukan dari pihak sekolah, karena memang di SD memang tidak ada bimbingan konseling jadi ada nya bimbingan konseling itu lebih dari guru wali kelas masing-masing, jadi dibimbing oleh kelas di kelas.

Hasil wawancara di atas dapat disimpulkan bahwa guru memberikan layanan bimbingan konseling dengan melakukan pendekatan individu untuk mengetahui permasalahan yang dihadapi siswa agar bisa memberikansolusi yang terbaik dan sesuai dengang kebutuhan siswa.

2. Apa sajakah fungsi layanan bimbingan konseling?

Hasil wawancara dengan guru kelas I yang berinisial RS menyatakan bahwa banyak fungsinya, untuk mengenal ciri pribadi menjelaskan makna sifat menggambarkan tanggung jawab masing-masing, mengenal karakteristik orang lain bagaimana menjelaskan makna kebersamaan bagaimana menggambarkan perasaan dalam berbagai situasi dan menggambarkan perasaan telah dibuat oleh amsing-masing, hasil wawancara dengan guru kelas II dengan inisial EL menyatakan bimbingan konseling itu ya layanannya seperti hubungan antara erat mahasiswi dan mahasiswa dengan kepada siswa siswi SD N 43.

Guru kelas III dengan inisial FD menyatakan memperbaiki karakter anak menyelesaikan masalah anak, selanjutnya guru kelas IV dengan inisial MR menyatakan bahwa fungsinya adalah merobak karkater anak akhlak yang kurang bagus kita ajak ke lebih akhlak yang bagus.

Selanjutnya guru kelas V dengan Inisial MW menyatakan bahwa untuk membimbing siswa yang bermasalah, sedangkan guru kelas VI dengan inisial EL menyatakan bahwa fungsi layanannya itu untuk memperbaiki perilaku anak lebih ke akhlaknya jadi kalau misalnyapun adanak bermasalah itu mungkin gurunya bisa menyelesaikan semampunya.

Kesimpulan dari hasil wawancara adalah fungsi layanan bimbingan konseling yang dilakukan untuk memberikan bimbingan kepada siswa agar menjadi pribadi yang 
lebih baik. Guru berupaya agar siswa dapat menjadi manusia yang memiliki pendidikan dan moral yang baik.

3. Apasajakah bimbingan yang diberikan pada siswa?

Wawancara dengan guru kelas I yang berinisial RS menyatakan bahwa bimbingan itu banyak bermacam-macam ada bimbingan anak yang lagi malas belajar yang sering tidak bahwa pensil yang sering nakal atau mengganggu temannya yang lagi belajar yang jalan-jalan di dalam kelas itu kita beri bimbingan kepada anak tersebut, hasil wawancara dengan guru kelas II dengan inisial EL menyatakan bimbingan konseling yang kami berikan kepada siswa yang bermateri supaya siswa itu terutama ialah berakhlak dan bermoral itu yang terutama dari dasar kami belajar di SD Negeri 43

Guru kelas III dengan inisial FD menyatakan menasehati memberikan sanksi apabila anak yang kita bimbing itu kemudian membuat perjanjian, selanjutnya guru kelas IV dengan inisial MR menyatakan bahwa bimbingan yang kita berikan pada siswa yaitu menasehati membimbing dia yang ada masalah kita tuntaskan dengan pelan-pelan, sehingga menjadi baik.

Guru kelas V dengan Inisial MW menyatakan bahwa permasalahan biasanya dalam hal perselisihan di atara siswanya, sedangkan guru kelas VI dengan inisial EL menyatakan bahwa bimbingan menasehati lebih ke merangkul, memberi dia untuk lebih mengerti bahwa setiap ada masalah tidak harus dengan emosi dia karena kan kalau anak-anak masih lebih kali masih butuh perhatian yang lebih.

Berdasarkan uraian diatad dapat disimpulkan bimbingan yang diberikan kepada siswa berupa nasihata dan juga contoh teladan agar siswa dapat menerapkannya dalam kehidupannya. Bimbingan ini dilakukan secara rutin dalam proses pembelajaran dio kelas.

4. Bagaimanakah cara guru memberikan bimbingan pada siswa?

Hasil wawancara dengan guru kelas I yang berinisial RS menyatakan bahwa sebenarnya, peran guru itu adalah mengembangkan kemampuan dan membentuk watak seseorang siswa untuk mencerdaskan kehidupan bangsa tujuannya untuk perkembangan potensi peserta didik, agar menjadi manusia berilmu dan bertaqwa kepada tuhan yang maha Esa, hasil wawancara dengan guru kelas II dengan inisial EL menyatakan ya, bimbingan pada siswa itu kami berikan kepada siswa -siswa yang berkebutuhan khusus seperti sisa-siswa contohnya siswa yang tidak dapat membaca ataupun kurang bisa membaca, siswa yang overdosis ataupun siswa-siswa yang nakal ataupun juga siswasiswa yang tidak bisa kami bina itupun kami akan panggil ke kantor untuk kami bina siswa-siswa tersebut.

Berdasarkan hasil wawancara dengan guru kelas III dengan inisial FD menyatakan saat menasehati menggunakan bahasa yang sopan kemudian anak yang bermasalah yang sopan dna mudah dipahami oleh anak, selanjutnya guru kelas IV dengan inisial MR menyatakan bahwa anak yang bermasalah kita panggil ke ruang khusus kita bombing dia supaya menjadi anak yang lebih bagus.

Berdasarkan hasil wawancara dengan guru kelas $\mathrm{V}$ dengan Inisial MW menyatakan bahwa melalui selesainya proses pembelajaran kami bombing setelah selesainya proses pembelajaran, sedangkan guru kelas VI dengan inisial EL menyatakan bahwa caranya dengan memanggil anak, menasehati, bicara terlebih dahulukan ada kata pengantar untuk anak misalnya bagaimana nak hari ini, pemuka dulu jangan langsung kita menanyakan bahwa ada masalah apa ini itu kan ngak mungkin juga jadi menasehati dulu secara pelan-pelan kemudian baru kita ke point misalnya apa yang sia hadapi. 
Kesimpulan dari uraian diatas adalah cara guru memberikan layanan konseling dimulai dari ccara yang sedderhana yaitu memberikan teguran, nasihat, sanksi hingga pemanggilan ke kantor kepala sekolah. Hal ini dilakukan agar siswa mengalami perubahan ke arah yang lebih baik

5. Siapa sajakah siswa yang mendapatkan bimbingan konseling?

Peneliti melakukan wawancara dengan guru kelas I yang berinisial RS menyatakan bahwa sebenarnya banyak yang kita ungkapkan tadi meskipun anak-anak yang harus kita bawa bombing itu banyak sekali, yang harus ita bombing itu banyak anak yang dalam belajarnya tidak ada konsentrasi kita akan tau kenapa dia tidak konsentrasi waktu belajar, saat belajar kita harus tau itu semuanya apakah keluarganya atau lingkungannya, atau temannya, baru kita Tanya kita lihat kita pantau dan kita memberi pelajaran itu. Kita liat anak sebagian bagaimana anak itu dalam mengahdapi pembelajaran yang kita berikan, hasil wawancara dengan guru kelas II dengan inisial EL menyatakan terutama anak-anak yang kurang konsentrasi dalam belajar baik itu factor dari keluarganya, lingkungan belajar atau teman-teman yang membuat dia menjadi kurang memahami dan mengerti dalam materi-materi belajar yang kita berikan kepada anak-anak tersebut.

Berdasarkan hasil wawancara dengan guru kelas III dengan inisial FD menyatakan anak yang bermasalah, selanjutnya guru kelas IV dengan inisial MR menyatakan bahwa anak yang mendapatkan masalah, misalnya mungkin apa masalah dirumah entah masalah di kelas bersama temanya dan lain apakah dengan guru itu perlu kita bimbing kekurangan khusus.

Berdasarkan hasil wawancara dengan guru kelas $\mathrm{V}$ dengan Inisial MW menyatakan bahwa anak yang bermassalah salah satunya seperti siswa kami M. daki siswa kelas VI, tapi kami selalu memberikan dia bimbingan supaya menjadi lebih baik lagi. sedangkan guru kelas VI dengan inisial EL menyatakan bahwa biasanya anakabak yang butuh perhatian lebih misalnya ada masalah broken home dirumahnya ada anak yang meninggal orangtuanya, mereka lebih butuh kasih sayang dari seseorang dan mungkin bisa didapatkan disekolah.

Hasil wawancara yang dilakukan dapat disimpulkan bahwa siswa yang mendapatkan bimbingan konseling biasanya siswa yang mengalami permaslaahan dalam belajar. Siswa yang bermasalah membutuhkan perhatian dan bimbingan dari guru.

6. Apakah bimbingan konseling yang diberikan pada siswa memberikan pengaruh yang positif?

Wawancara yang dilakukan dengan guru kelas I yang berinisial RS menunjukkan bahwa bahwa sangat positif banyak sekali perubahannya dalam memberikan bimbingan atau arahan bagisiswa yang bermasalah atau bagi siswa yang menghadapi kejadian atau sesuatu yang dialaminya,waktu pertama bimbingan mereka akan memahami atau akan mengerti apa yang sebenanrnya yang kita telah beri bimbingan kepada anak pertama sekali bagi anak didik kita yang kelas 1. Bagaimana cara yang harus betul-betul kita jeli dan bijaksana dalam mengahdapi segala tingkah laku mereka yang kita didik saat kita melakukan pembelajaran. hasil wawancara dengan guru kelas II dengan inisial EL menyatakan bimbingan konseling yang kita berikan kepada siswa itu

Berdasarkan hasil wawancara dengan guru kelas III dengan inisial FD menyatakan ya ada pengaruhnya karena dengan konseling tersebut anak bermasalah ke orang yang lebih baik. selanjutnya guru kelas IV dengan inisial MR menyatakan 
bahwa tentu bisa memberi pengaruh yang positif bagi anak yang kita bombing, bagi anak yang bermasalah setelah kita bombing insya Allah bisa menajdi lebih baik.

Berdasarkan hasil wawancara dengan guru kelas $\mathrm{V}$ dengan Inisial MW menyatakan bahwa sudah positif. sedangkan guru kelas VI dengan inisial EL menyatakan bahwa biasanya kalau terjadi positif atau enggaknya kita belum bisa melihat dalam sehari-hari itu karenakan bisa dilihatnya setiap minggu bahwa hari ini misalnya ada perubahan anak untuk misalnya hari ini sikap dia jauh lebih dari kemarin, contohnya dia hari ini jauh lebih bisa menghormati temannya menghargai temannya dengan kita tadi sudah kasih masukan kepada anak tersebut.

Hasil wawancara menunjukkan bahwa layanan bimbingan konseling memberikan pengaruh yang positif terhadap siswa, khususnya siswa yang bermasalah di sekolah. Ada siswa yang berubah secara bertahap dan ada juga siswa yang berubah lebih baik setelah mendapatkan satu atau dua kali bimbingan saja. Hasil wawancara dengan guru kelas I yang berinisial RS menyatakan bahwa waktunya kita tentukan apakah kita lakukan di dalam kelas ataupun di ruang kelas simanasaja kita memberikan konseling itu ataupun sentuhan -sentuhan atau dapat kita lakukan konsleing itu dengan rasa nyaman meraka itu atau paling lama itu satu atau setengah jam yang kita berikan konseling pada anak didik kita, hasil wawancara dengan guru kelas II dengan inisial EL menyatakan ya, waktu yang kami berikan bimbingan konseling itu pada saat-saat jam belajar kami panggil anak-anaktersebut ke kantor untuk kami bina dan memberikan bimbingan konseling.

Berdasarkan hasil wawancara dengan guru kelas III dengan inisial FD menyatakan setiap anak yang bermasalah. selanjutnya guru kelas IV dengan inisial MR menyatakan bahwa disaat anak-anak sudah berulang-ulang membuat masalah

Berdasarkan hasil wawancara dengan guru kelas V dengan Inisial MW menyatakan bahwa setelah selesai proses belajar mengajar. sedangkan guru kelas VI dengan inisial EL menyatakan bahwa pada saat istirahat jam istirahat boleh pulang sekolah itu bisa dijadikan anak tersebut untuk kita panggil sendiri jadi tanpa ada mengganggu jam pelajarannya.

Berdasarkan hasil wawancara dapat disimpulkan bahwa waktu bimbingan dilakukan bersamaan pada saat proses pembelajaran dilakukan, akan tetapi guru juga sering melakukan bimbingan secara pribadi setelah proses pembelajaran berlangsung agar siswa mau berbicara lebih banyak mengenai permasalahan yang dihadapinya.

7. Apakah yang dilakukan jika siswa tidak mengalami perubahan setelah bimbingan konseling?

Hasil wawancara dengan guru kelas I yang berinisial RS menyatakan bahwa mereka sangat banyak mendapat perubahan atau mendapat pelajaran dari guru yang telah mendidiknya dengan guru memberikan arahan-arahan yang sepatutnya guru memberikan kepada mereka itu agar mereka memahami apa perbuatannya yang mereka lakukan itu baik atau tidak dengan bimbingan konseling ini kita dapat melakukan kebijakan atau nasehat demi nasehat agar anak ini memahami dan menghayat apa yang telah kita berikan saat ini, hasil wawancara dengan guru kelas II dengan inisial EL menyatakan yah, apabila siswa siswi kami tersebut telah kam beri bimbingan konseling tapi mereka tidak ada perubahan kamipun para dewan guru akan mencoba dan berusaha berulang kali agar si anak ataupun siswa siswi tersebut dapat berubah yang kami lakukan itu saja.

Guru kelas III dengan inisial FD menyatakan pihak sekolah memanggil orang tua. selanjutnya guru kelas IV dengan inisial MR menyatakan bahwa apabila anak tidak 
berubah juga setelah kita bombing kita perlu melakukan pengamatan dan memanggil orangtuanya

Guru kelas V dengan Inisial MW menyatakan bahwa terus kita lanjutkan tahap kedua untuk melanjutkan membimbingnya. sedangkan guru kelas VI dengan inisial EL menyatakan bahwa mungkin akan lebih kita telusuri apa masalahnya, lebih misalnya pertama kita panggil anaknya kemungkinan besar kita bisa kerumah anak ataupun kita bisa memanggil sia untuk sendiri kita mengajak dia atau kita bicara lebih dalam lagi terhadap anak supaya dia bisa membuka lagi apa yang sebenarnya atau masalah apa yang sebenaranya dia alami ataupun sebagian anakkan tidak bisa terbuka dengan masalahnya tapi kita bisa mengorek informasi bahwa apa yang terjadi dengan anak tersebut.

Berdasarkan hasil wawancara dapat disimpulkan bahwa banyak siswa mendapatkan perubahan setelah dilakukan bimbingan konseling.

8. Kapan waktu yang ditentukan dalam memberikan bimbingan konseling?

Hasil temuan lapangan juga menunjukkan bahwa guru kelas I yang berinisial RS menyatakan bahwa layanan belajar yang diberikan merupakan bantuan yang diberikan kepada individu dalam mencocokkan masalah kesulitan belajar baik di sekolah maupun diluar sekolah agar individu dapat mencelahkan diri dalam situasi belajar dengan baik, layanan bimbingan belajar yang di maksud adalah tindakan atau usaha dalam melakukan proses pembelajaran bantuan terhadap peserta didik yang mengalami kesulitan dalam belajar, hasil wawancara dengan guru kelas II dengan inisial EL menyatakan ya, waktu yang kami berikan bimbingan konseling itu pada saat jam belajar kami panggil anak-anak tersebut ke kantor untuk kami bina dan memberikan bimbingan konseling.

Guru kelas III dengan inisial FD menyatakan tingkah laku anak. selanjutnya guru kelas IV dengan inisial ML menyatakan bahwa disaat anak-anak sudah berulangulang membuat masalah.

Berdasarkan wawancara dengan guru kelas V dengan Inisial MW menyatakan bahwa untuk tahun ini gak ada, mungkin tahun-tahun yang dulu ada siswa yang susah dibilanginnya, kalau sekarang ngak ada, sedangkan guru kelas VI dengan inisial EL menyatakan bahwa mungkin untuk memasukkan argument kita pendapat kita atau solusi kita terhadap anak karenakan tidak semua snak itu pemikirannya sama sementara jika anak kelas VI tingkat kelas itu mungkin lebih udah lumayan paham, tapi kalau misalkan kelas bawah itu tidak semuanya mereka mengerti dengan bahasa yang kita katakana mungkin lebih lembut lagi.

Hasil analisis wawancara menunjukkan bahwa guru melakukan layanan bimbingan konseling lebih intensif kepada siswa yang tidak mengalami perubahan setelah dibimbing. Proses bimbingan dilakukan berulang kali dan dalam jangka waktu yang lebih panjang. Selain itu, guru juga lebih banyak berbicara dari hati ke hati agar siswa bisa mengutarakan sumber masalahnya. Guru menghadapi kendala dalam memberikan layanan bimbingan konseling kepada siswa, khususnya yang berkaitan dengan waktu. Guru harus membagi waktu mengajar dan membimbing siswa. Selain itu, siswa banyak yang tertutup dalam mengemukakan masalah yang dihadapinya, sehingga guru harus berusaha mencari tahu agar dapat menemukan solusi terbaik bagi siswa.

9. Apakah kesulitan yang anda hadapi dalam memberikan bimbingan konseling?

Hasil wawancara dengan guru kelas I yang berinisial RS menunjukkan bahwa layanan belajar yang di aturkan sebagai bantuan yang di berikan kepada individu dalam mencobakan masalah kesulitas belajar baik di skeolah maupun diluar sekolah 
agar individu dapat mecelahkan diri dalam situasi belajar dengan baik, layanan bimbingan belajar yang di maksud adalah tindakan atau usaha dalam melakukan proses pembelajaran bantuan tindakan atau usaha dalam melakukan proses pembelajaran bantuan terhadap peserta didik yang mengalami kesulitan dalam belajar.

Hasil wawancara dengan guru kelas II dengan inisial EL menyatakan yang kami alami apabila memberikan konseling itu si anak datang ke sekolah kadang-kadang apabila ada waktu-waktu tertentu kami akan memberikan bimbingan konseling si anak tidak hadir kesekolah dan orangpun yah kurang begitu memperlihatkan si anak.

Guru kelas III dengan inisial FD menyatakan tingkah laku anak. selanjutnya guru kelas IV dengan inisial ML menyatakan bahwa kesulitannya adalah anak di saat kita beri bimbingan itu sekali belum berobah dan kedua kali juga tidak berobah sampai ke tiga kali tidak berubah kita langsung melaporkan ke kepala sekolah untuk dinasehati atau di tindak lanjuti sebagai mana mungkin.

Berdasarkan wawancara dengan guru kelas V dengan Inisial MW menyatakan bahwa untuk tahun ini gak ada, mungkin tahun-tahun yang dulu ada siswa yang susah dibilanginnya, kalau sekarang ngak ada, sedangkan guru kelas VI dengan inisial EL menyatakan bahwa mungkin untuk memasukkan argument kita pendapat kita atau solusi kita terhadap anak karenakan tidak semua snak itu pemikirannya sama sementara jika anak kelas VI tingkat kelas itu mungkin lebih udah lumayan paham, tapi kalau misalkan kelas bawah itu tidak semuanya mereka mengerti dengan bahasa yang kita katakana mungkin lebih lembut lagi

10. Apakah manfaat yang paling dirasakan siswa setelah mendapatkan bimbiingan konseling?

Hasil wawancara menunjukkan bahwa guru kelas I yang berinisial RS menyatakan bahwa banyak sekali manfaatnya bimbingan yang telah kita berikan sehingga diri kita merasa lebih baik dan bahagia tenang dan nyaman, karena bimbingan konseling tersebut membuat kita untuk menerima setiap siswa yang ada di dalam diri kita dan membantu menurunkan stress bagi kita dan memberikan dan menerima diri kita sendiri dan orang lain, hasil wawancara dengan guru kelas II dengan inisial EL menyatakan wow, itu sangat bermanfaat kepada siswa setelah kami memberikan konseling perubahan dratis pada anak itu tidak begitu langsung tetapi pelan-pelan si anak berubah watak ataupun karakter setelah kami memberikan bimbingan konsleing sekian.

Guru kelas III dengan inisial FD menyatakan anak berubah menjadi lebih baik lagi, selanjutnya guru kelas IV dengan inisial ML menyatakan bahwa manfaatnya sangat cukup bagus banyak anak mnegalami perubahan setelah di bombing oleh gurunya.

Berdasarkan wawancara dengan guru kelas V dengan Inisial MW menyatakan bahwa perkembangannya luar biasa yang dulu anak-anak pernah mau menurut dalam hal lomba tidak mau ikut tapi Alhamdulillah setelah ikut bimbingan ini benar-benar berpartisipasi untuk ikut lomba dan sudah sering dapat juara Alhamdulillah. sedangkan guru kelas VI dengan inisial EL menyatakan bahwa kalau misalnya mamfaat yang paling kita rasakan sebagai guru saya belum tau apa tapi kalu kita melihat mungkin mereka lebih merasakan bahwa mereka diperhatikan bahwa mereka ada mendapat kasih saying, walaupun tidak dapat dirumah, tetapi di sekolah ada walaupun tidak seutuhnya.

Hasil analisis wawancara menunjukkan bahwa layanan bimbingan konseling dilaksanakan di SD Negeri 43 Banda Aceh. Layanan ini dilakukan untuk membimbing siswa yang mengalami permasalahan dalam belajar baik. Guru memberikan arahan terutama bagi anak-anak yang kurang konsentrasi dalam belajar baik yang disebabkan 
faktor dari keluarga, lingkungan belajar atau teman-teman yang membuat dia menjadi kurang memahami dan mengerti dalam materi-materi belajar yang kita berikan kepada anak-anak tersebut.

Hasil pengamatan observasi diatas dapat disimpulkan bahwa guru selalu memberikan bimbingan konseling kepada anak, guru mengidentifikasikan kondisi siswa, guru selalu memberikan bimbingan melalui pendekatan individual selanjutnya guru mengarahkan siswa untuk melakukan hal-hal yang positif dan guru menegaskan hal-hal yang harus dihindari siswa, dan melakukan evaluasi terhadap perkembangan perilaku siswa. guru terus memberikan bimbingan berulang kepada siswa dan menasehati siswa.

Hasil perbandingan yang dilakukan sesuai dengan penelitian yang dilakukan oleh Kamaludin (2011) dengan judul "Bimbingan dan Konseling di Sekolah". Hasil dari penelitian ini adalah pelaksanaan layanan bimbingan dan konseling belum dapat dilaksanakan secara maksimal. Hambatan yang muncul adalah jumlah guru bimbingan dan konseling di masing-masing sekolah belum sesuai dengan ratio guru BK belum sepenuhnya menguasai dan memiliki kompetensi sebagai konselor, guru BK umumnya belum menguasai pengetahuan yang harus dimiliki oleh seorang konselor, serta guru BK masih bertugas rangkap.

\section{Kesimpulan}

Hasil penelitian yang berkaiatan dengan pelaksanaan layanan bimbingan konseling oleh guru kelas menyimpulkan bahwa: Penerapan layanan bimbingan konseling telah dilakukan oleh guru kelas di SD Negeri 43 Banda Aceh. Guru melakukan bimbingan konseling dengan cara mengidentifikasi permasalahan yang dihadapi siswa berkaitan dengan pembelajaran di dalam kelas maupun di luar kelas. Setelah mengetahui siswa yang bermaslah dan membutuhkan layanan bimbingan, guru memberikan arahan dan bantuan bagi siswa agar dapat mecari solusi dari permasalahan yang dihadapi.

\section{DAFTAR PUSTAKA}

Abu bakar M. Luddin, Dasar-Dasar Konseling, Bandung: Cita pustaka Media Perintis, 2010.

A.M., Sardiman. 2001. Interaksi Dan Motivasi Belajar Mengajar. Jakarta: Raja Grafindo Persada

Kemendikbud. 2014. Permendikbud No 111 Tahun 2014 tentang Bimbingan Konseling. Jakarta: Kementrian Pendidikan dan Kebudayaan

Prayitno, 2017. Panduan Kegiatan Pengawasan Bimbingan dan Konseling di Sekolah,. Jakarta: Rineka Cipta

Radjah, C. L. (2016). Keterampilan konseling berbasis metakognisi. Jurnal Kajian Bimbingan dan Konseling, 1(3), 90-94.

Sugiyono, 2017. Metode Penelitian Kuantitatif, Kualitatif, dan R\&D. Bandung : Alfabeta

Sutirna, M.Pd.2013. Perkembangan dan Pertumbuhan Peserta Didik. ANDI OFFSET. Yogyakarta. 